\title{
Potential of Interdigitated Back-Contact Silicon Heterojunction Solar Cells for Liquid Phase Crystallized Silicon on Glass with Efficiency above $14 \%$
}

\author{
Cham Thi Trinh ${ }^{\mathrm{a}, *}$, Natalie Preissler ${ }^{\mathrm{a}, \mathrm{b}}$, Paul Sonntag ${ }^{\mathrm{a}}$, Martin Muske ${ }^{\mathrm{a}}$, Klaus Jäger ${ }^{\mathrm{c}}$, Martina \\ Trahms $^{\mathrm{a}}$, Rutger Schlatmann ${ }^{\mathrm{b}}$, Bernd Rech ${ }^{\mathrm{a}}$, Daniel Amkreutz ${ }^{\mathrm{a}}$ \\ ${ }^{a}$ Institute for Silicon Photovoltaics / Helmholtz-Zentrum Berlin für Materialien und Energie \\ $\mathrm{GmbH}$, Berlin, Germany \\ ${ }^{\mathrm{b}}$ PVcomB / Helmholtz-Zentrum Berlin für Materialien und Energie GmbH, Berlin, Germany \\ ${ }^{c}$ Young Investigator Group Nano-SIPPE / Helmholtz-Zentrum Berlin für Materialien und \\ Energie GmbH, Berlin, Germany
}

*Corresponding author. Tel: +49 (0)30 8062-41385, Email address: cham.trinh@ @elmholtzberlin.de

\begin{abstract}
Liquid phase crystallization of silicon (LPC-Si) on glass is a promising method to produce high quality multi-crystalline Si films with macroscopic grains. In this study, we report on recent improvements of our interdigitated back-contact silicon heterojunction contact system (IBC-SHJ), which enabled open circuit voltages as high as $661 \mathrm{mV}$ and efficiencies up to $14.2 \%$ using a $13 \mu \mathrm{m}$ thin n-type LPC-Si absorbers on glass. The influence of the BSF width on the cell performance is investigated both experimentally and numerically. We combine 1D optical simulations using GenPro4 and 2D electrical simulations using Sentaurus ${ }^{\mathrm{TM}}$ TCAD to determine the optical and electrical loss mechanisms in order to estimate the potential of our current LPC-Si absorbers. The simulations reveal an effective minority carrier diffusion length of $26 \mu \mathrm{m}$ and further demonstrate that a doping concentration of $4 \times 10^{16} \mathrm{~cm}^{-3}$ and a back surface field width of $60 \mu \mathrm{m}$ are optimum values to further increase cell efficiencies.
\end{abstract}

\section{Introduction}

Renewable energy revolution has boosted the growth of photovoltaic industry in recent years. According to international technology roadmap for photovoltaics (ITRPV), the levelized cost of electricity (LCOE) will continuously decrease and the price of large-scale systems is estimated to drop to $680 \mathrm{US} \$ / \mathrm{KWp}$ in the next 10 years [1]. One main key for cost reduction is saving material during the cell fabrication process, in particular, Silicon as it accounts for up to $40 \%$ of the cell price [2]. Therefore, in the past a lot of technologies were developed to fabricate high-quality c-Si thin films [3], such as solid phase crystallization (SPC) [4], seed layer approach (i.e. metal induced crystallization (ALILE) [5]) or direct crystalline epitaxial growth [6]. However, these technologies suffered from a high defect density in the bulk, limiting the achievable open circuit voltage $\left(V_{o c}\right)$ to $560 \mathrm{mV}$ [7]. Liquid phase crystallization of silicon 
(LPC-Si) is a promising method to grow large-grain silicon film on glass by using line-shaped energy sources, such as a laser or an electron beam [8]. This method is able to crystallize thin Si films with thicknesses as high as $40 \mu \mathrm{m}$ and with grain size up to centimeters in length and a few millimeters in width [9-11]. A high open circuit voltage $\left(V_{o c}\right)$ of $656 \mathrm{mV}$ was achieved with a $10 \mu \mathrm{m}$-thick LPC-Si absorber [10], which is close to the $V_{o c}$ of conventional multicrystalline Si $[10,12]$. This absorber was crystallized by an electron beam and a stable efficiency of $11.5 \%$ was obtained for a back-contacted solar cell design [10]. The LPC-Si technique based on a continuous wave electron beam was developed by Amkreutz et al.. A later study showed no detectable difference in bulk quality of the Si absorber crystallized by laser or e-beam [13]. Optimization of the crystallization process and a mature interface engineering of the intermediate layers (ILs) between glass and $\mathrm{Si}$ are crucial steps to enhance absorber quality. ILs have to fulfill a variety of requirements, such as providing adhesion during the crystallization process, preventing impurity diffusion from glass, acting as antireflective coating, and passivating interface defects. The ILs are mainly based on amorphous silicon oxide $\left(\mathrm{SiO}_{x}\right)$, amorphous silicon nitride $\left(\mathrm{SiN}_{x}\right)$, amorphous silicon oxynitride $\left(\mathrm{SiO}_{x} \mathrm{~N}_{y}\right)$, amorphous silicon carbide $\left(\mathrm{SiC}_{x}\right)$ and aluminum oxide $\left(\mathrm{AlO}_{x}\right)$ prepared by plasma-enhanced chemical vapor deposition (PECVD), reactive RF-magnetron sputtering (PVD) or atomic layer deposition (ALD) [7, 14-20]. Dore et al. found that the layer in direct contact to the Silicon plays a significant role on enhancing electronic quality of the absorber and the best efficiency for LPC-Si solar cell on glass was realized by a triple stack of $\mathrm{SiO}_{\mathrm{x}} / \mathrm{SiN}_{\mathrm{x}} / \mathrm{SiO}_{\mathrm{x}}(\mathrm{ONO})$ [16]. Amkreutz et al. also reported a $V_{o c}$ above $620 \mathrm{mV}$ and an efficiency up to $11.8 \%$ for a backcontacted solar cell with laser crystallized $\mathrm{Si}$ on glass with a sputtered ONO stack [13]. For PECVD ONO layers, an annealing step needs to be conducted in order to release mobile hydrogen in ILs, which is detrimental for crystallization. An efficiency of $12.1 \%$ was obtained with a LPC-Si absorber using PECVD $\mathrm{SiN}_{\mathrm{x}} / \mathrm{SiO}_{\mathrm{x}} / \mathrm{SiO}_{\mathrm{x}} \mathrm{N}_{\mathrm{y}}$ for a point contact cell assisted by a light trapping scheme [20]. Recently, Preissler et al. realized that a nitrogen-rich $\mathrm{SiN}_{\mathrm{x}}$ layer in a PECVD ONO stack layer enables adhesion without prior annealing [15]. The absence of Si$\mathrm{H}$ bonds in the $\mathrm{SiN}_{\mathrm{x}}$ structure enhances its stability during crystallization by avoiding $\mathrm{H}$ desorption, thus, preventing peeling off. The interdigitated back-contact silicon heterojunction (IBC-SHJ) solar cell based on LPC-Si on glass was firstly introduced by Sonntag et al. [21]. However, the obtained efficiencies $<10 \%$ were limited by low fill factors $(<55 \%)$. Recently, based on ONO IL developed by Preissler et al., a high efficiency of $13.2 \%$ was achieved for IBC-SHJ solar cells for $13 \mu \mathrm{m}$-thick n-type LPC-Si on glass [22, 23]. This outstanding result was obtained for both high and low doping Si absorber with fill factors of $74.7 \%$ and $67.2 \%$, respectively, thanks to improvement in IL engineering, optimum geometric design and cell fabrication processes. However, optimization of the contact system geometries has not been clarified yet. For IBC-SHJ cells, all contacts are placed at the back-side of the absorber, therefore, an ideal geometry is necessary to collect as much current as possible without causing resistive loss or electric shading. For the best cell efficiency with an emitter ratio of $90 \%$ (back surface field (BSF) width of $120 \mu \mathrm{m}$ ), almost no current was collected under the BSF finger region due to limitations of the minority diffusion length $(<30 \mu \mathrm{m})$. Analysis on light beam induced current (LBIC) mapping revealed that $11 \%$ of the loss in short circuit current density $\left(J_{s c}\right)$ is dedicated to the BSF fingers and their surrounding area. Therefore, in this study, we focus on developing the geometric structure for IBC-SHJ solar cells for LPC-Si on glass. We firstly work on numerical simulation for the IBC structure to examine the effect of BSF width 
on the cell performance. Then, experimental results of real IBC-SHJ cells with various BSF widths are reported.

\section{Sample preparation and characterization}

\subsection{Absorber fabrication}

Firstly, $10 \times 10 \mathrm{~cm}^{2}$ cleaned aluminosilicate glass substrates (Corning Eagle XG, $1.1 \mathrm{~mm}$ thickness) were coated with different ILs. The ILs used in this study include $\mathrm{SiO}_{\mathrm{x}} / \mathrm{SiN}_{\mathrm{x}}(\mathrm{ON})$, $\mathrm{SiO}_{\mathrm{x}} / \mathrm{SiN}_{\mathrm{x}} / \mathrm{SiO}_{\mathrm{x}}(\mathrm{ONO})$ with a $15 \mathrm{~nm}$-thick $\mathrm{SiO}_{\mathrm{x}}$ passivation layer and $\mathrm{ON}(\mathrm{ON})$ stack layer in which $\mathrm{SiO}_{\mathrm{x}} / \mathrm{SiN}_{\mathrm{x}}$ was oxidized by a $\mathrm{N}_{2} \mathrm{O}$ plasma for $10 \mathrm{~min}$. Due to this oxidation process a 10 nm-thick $\mathrm{SiO}_{\mathrm{x}} \mathrm{N}_{\mathrm{y}}$ film can be deposited in a controlled and reproducible way. This process is also considered to increase the homogeneity of the layer in direct contact to the absorber and thus, to provide less scattering of the cell results. Details on the interlayer development and deposition process are described in Ref. [24]. A $14.7 \mu \mathrm{m}$-thick undoped silicon layer was deposited on top of the ILs using electron-beam evaporation at a heater temperature of $600^{\circ} \mathrm{C}$ and deposition rate of roughly $600 \mathrm{~nm} / \mathrm{s}$. An $80 \mathrm{~nm}$-thick phosphorous doped a-Si:H (n+) film was then deposited acting as doping source for the LPC-Si absorber layer. Samples were finally coated with a $100 \mathrm{~nm} \mathrm{SiO}_{x}$ layer to avoid dewetting during crystallization under vacuum conditions. All layers were deposited using a Von Ardenne CS400PS integrated CVD/PVD cluster tool. The crystallization process was carried out in a vacuum system using a line-shape continuous wave diode laser $(808 \mathrm{~nm})$ at a scan speed of $3 \mathrm{~mm} / \mathrm{s}$ (power density $<3 \mathrm{~kW} / \mathrm{cm}^{2}$ ). Vacuum conditions were chosen to avoid contamination during the crystallization process. In accordance with the geometry of the laser line of $52 \times 0.3 \mathrm{~mm}^{2}$, samples were cut into four $5 \times 5$ $\mathrm{cm}^{2}$ subsamples. Before crystallization, samples were preheated to $500^{\circ} \mathrm{C}$ surface temperature to reduce thermal stress during crystallization. After crystallization, stress in the glass substrates was released by rapid thermal annealing at $950^{\circ} \mathrm{C}$. The $\mathrm{SiO}_{\mathrm{x}}$ cap was removed with diluted hydrofluoric acid (HF, 5\%) before a hydrogen plasma treatment was performed to passivate the Si bulk. Damaged Si was removed with an aqueous solution consisting of $\mathrm{HF}$, nitric acid $\left(\mathrm{HNO}_{3}\right)$, and phosphoric acid $\left(\mathrm{H}_{3} \mathrm{PO}_{4}\right)$. Subsequently the samples were textured with a potassium hydroxide $(\mathrm{KOH})$-based solution with Alkatex free+ additive at $80^{\circ} \mathrm{C}$ for 3 min, resulting in pyramid sizes of 1.5-2.0 $\mu \mathrm{m}$ on initial (100) surface. For other surface orientations, the pyramids are tilted by various angles up to flat surfaces for the (111) orientation. The final thickness of the Si absorber is around $13 \mu \mathrm{m}$.

\subsection{IBC-SHJ cell fabrication}

For this study, cells were designed with various BSF widths ( $\left.W_{B S F}\right)$ of $240 \mu \mathrm{m}, 120 \mu \mathrm{m}$, $90 \mu \mathrm{m}$ and $60 \mu \mathrm{m}$. The emitter finger width $\left(W_{\text {emitter }}\right)$ was kept unchanged at $1080 \mu \mathrm{m}$. All cells

were designed to have an area of $(1 \times 0.6) \mathrm{cm}^{2}$. The cell fabrication consists of several photolithography steps (Resist: Microchemicals AZ 4533, mask aligner: MA6 SÜSS MicroTec) used for structuring. Top views of the back side of a cell after each layer structuring step are shown in Fig. 1 (a)-(c). The schematic cross section of the cell is depicted in Fig. 1 (d). We followed the cell fabrication processes as described in Refs. [20, 22]. The samples were cleaned with a standard RCA cleaning process before cell fabrication. Subsequently, a-Si:H (i/ $\left.\mathrm{p}^{+}\right)$ emitter layers were deposited by PECVD. The layers were then structured by photolithography. 
A metal-ion-free tetramethylammonium hydroxide (TMAH) $2.5 \%$ solution was employed for development. The hetero-emitter was etched using an aqueous solution consisting of HF, $\mathrm{HNO}_{3}$, and $\mathrm{H}_{3} \mathrm{PO}_{4}$. After another RCA cleaning step, the samples were covered with an a-Si:H $\left(\mathrm{n}^{+}\right)$layer by PECVD and then structured to form the BSF. We used TMAH 2.5\% solution for developing and etching the exposed BSF areas [22]. The overlap of the a-Si:H $\left(\mathrm{p}^{+}\right)$and a-Si:H $\left(\mathrm{n}^{+}\right)$regions is $15 \mu \mathrm{m}$ in the mask design and it reduces to $8 \mu \mathrm{m}$ due to over-etching after patterning. Please notice that $W_{B S F}$ doesn't include this overlap width, as shown in Fig. 1(d). These intrinsic, boron doped (for emitter) and phosphorus doped (for BSF) Si-films have thicknesses of $7 \mathrm{~nm}, 15 \mathrm{~nm}$ and $10 \mathrm{~nm}$ on the textured surface, respectively. Electrodes of 120$\mathrm{nm}$ thick indium-tin-oxide (ITO) and $1 \mu \mathrm{m}$-thick silver (Ag) films were deposited in a sputtering process. A final photolithography step was done to structure the electrodes on the emitter and BSF. We employed Hydrochloric acid ( $\mathrm{HCl})(20 \%)$ for ITO etching and diluted mixture of ammonia solution $\left(\mathrm{NH}_{4} \mathrm{OH}\right)$ and hydrogen peroxide $\left(\mathrm{H}_{2} \mathrm{O}_{2}\right)$ for Ag etching. In order to cure damage during ITO sputtering, samples were annealed in an oven at $180{ }^{\circ} \mathrm{C}$ for $20 \mathrm{~min}$.

\subsection{Cell characterization}

Current-voltage $(J-V)$ curves were obtained using an AAA-rated solar simulator of type Wacom WXS-156S-L2, AM1.5GMM with dual sources (halogen and xenon lamp). Suns-Voc measurements were performed by Sinton Instruments (Boulder, CO, USA). Reflection $(R)$ and transmission $(T)$ spectra were measured with a PerkinElmer LAMBDA 1050 spectrophotometer. The doping concentration $\left(N_{D}\right)$ of the samples was calculated via the sheet resistance, which was obtained by a four point probe measurement. The sheet resistance was measured in at least 12 different points for each $5 \times 5 \mathrm{~cm}^{2}$ sample and the average value was taken from all samples. Hole and electron mobilities are assumed to be at $80 \%$ of the hole and electron mobilities of mono c-Si, which is in good agreement with measured mobilities obtained by Hall measurements [22]. The series resistance $\left(R_{s}\right)$ was determined by comparing dark and illuminated $J-V$ curves [25]. The surface morphology of the textured absorbers was obtained by an atomic force microscope. The a-Si:H film thickness and the optical properties (refractive index and extinction coefficient) were obtained by spectroscopic ellipsometry, using TaucLorentz model.

\section{Results and discussion}

\section{1. $2 D$ simulation}

The effect of $W_{B S F}$ on the performance of IBC-SHJ cells was simulated with the TCADSentaurus ${ }^{\mathrm{TM}}$ device simulator [26]. Since our samples are back-side textured, it is challenging to simulate the correct optical properties. Therefore, a photon generation profile would be more appropriate to display photon absorption in a real IBC cell. One problem is that the absorption extracted from measured reflectance and transmission data includes parasitic absorption of the supporting layers, such as a-Si:H or ITO. In order to determine the absorption in these layers, we performed optical simulations with the MATLAB-based program GenPro4, which is developed at the Delft University of Technology [27], and utilizes the transfer-matrix method. The pyramidal morphology of the samples was taken into account using the ray tracing model included in GenPro4. We used complex refractive index $(n, k)$ data of glass [28], c-Si [29], ITO 
[30], and $\mathrm{Ag}$ [31] reported in literature. The optical properties of all other layers were individually determined by spectroscopic ellipsometry. The absorption spectrum of each layer is shown in Fig. 2 (b). The blue dotted curve displays experimentally measured absorption $(1-R-T)$ of a real IBC cell. One can see a good match between simulated and experimental data.

Due to multiple reflections in the layer stack, the generation profile in the silicon layer cannot be derived with the Lambert-Beer law. We estimated the generation profile in the silicon layer with the following assumption: light passes through the layer with an exponentially decaying intensity. At the back, the light is reflected back into the layer and again, the intensity decays exponentially and so forth, which mathematically is expressed via a geometric series. Following this assumption we can calculate the generation profile $G(z, \lambda)$,

$$
G(z, \lambda)=\Phi_{\mathrm{ph}, \lambda} A(\lambda) \alpha \frac{\exp (-\alpha z)+\exp (-2 d z) \exp (\alpha z)}{1-\exp (-2 d z)},
$$

where $\Phi_{\mathrm{ph}, \lambda}$ is the spectral photon flux from the AM 1.5 solar spectrum, $A(\lambda)$ is the absorption in the silicon layer extracted from GenPro4, $\alpha=\alpha(\lambda)$ is the absorption coefficient of silicon and $d$ is the thickness of the silicon layer. The reflectivity of both sides of the Si layer were estimated to be $100 \%$.

TCAD-Sentaurus ${ }^{\mathrm{TM}}$ was used to simulate the IBC cell performance. A front surface recombination velocity $\left(S R V_{\text {front }}\right)$ of $200 \mathrm{~cm} / \mathrm{s}$ is assumed since it was found to be a reasonable value for the present passivation quality of ONO ILs [22, 23]. For LPC-Si electrical quality, we used the Scharfetter model, in which Shockley-Read Hall (SRH) lifetime is doping dependent $[26,32,33]$. The Shockley-Read-Hall (SRH) lifetime is calculated as:

$$
\tau=\tau_{\min }+\frac{\tau_{\max }-\tau_{\min }}{1+\left(\frac{N_{D}+N_{A}}{N_{r e f}}\right)^{\gamma}}
$$

$\tau_{\min }=0$ and $\gamma=1$ were used for c-Si $[32,33] . N_{\text {ref }}$ of $7 \times 10^{15} \mathrm{~cm}^{-3}$ and $\tau_{\max }$ of $395 \mu$ s was found by fitting equation (2) with experimental carrier lifetime of c-Si [32], which has a bulk lifetime higher than LPC-Si. Therefore, suitable $N_{\text {ref }}$ and $\tau_{\max }$ values for LPC-Si need to be determined. To meet the purpose, we varied $\tau_{\max }$ and $N_{r e f}$ values to simulate $J_{s c}$ and $V_{o c}$ of the 13.2\% IBC cells with low doped and high doped absorber from Ref. [22]. The interface of a$\mathrm{Si}: \mathrm{H} / \mathrm{LPC}-\mathrm{Si}$ was described by introducing a thin defect layer. This defect layer is necessary to result in a good match between experimental and simulated $V_{o c}$ [13]. A $\tau_{\max }$ of $2.1 \mu \mathrm{s}$ and $N_{\text {ref }}$ of $7.5 \times 10^{16} \mathrm{~cm}^{-3}$ resulted in the best fit for these samples, as shown in Table 1 . As a result, $\tau$ of 1.8 $\mu \mathrm{s}$ and $0.8 \mu \mathrm{s}$ are obtained for low and high doped LPC-Si, respectively. Since we are focusing on intrinsic properties of LPC-Si on glass, the effective minority diffusion length $\left(L_{\text {eff }}\right)$ was calculated by neglecting back surface recombination. By using $S R V_{\text {front }}$ of $200 \mathrm{~cm} / \mathrm{s}, \tau$ of $1.8 \mu \mathrm{s}$ and $0.8 \mu$ s give $L_{\text {eff }}$ of $30 \mu \mathrm{m}$ and $20 \mu \mathrm{m}$, respectively. These $L_{\text {eff }}$ values are in good agreement with results obtained from previous device modeling of the other $13.2 \%$ efficiency cells using the ASPIN3 simulation package and light beam induced current (LBIC) measurement with line scan analysis [22, 34]. In this study, $N_{D}$ of $8 \times 10^{16} \mathrm{~cm}^{-3}$ was chosen for IBC cell simulation and experiment since it offers a reasonable compromise between $J_{s c}$ and $V_{o c}$ [13]. $\tau$ of $1.0 \mu \mathrm{s}$ was obtained for this doping concentration. With $\tau$ of $1.0 \mu \mathrm{s}$ and $S R V_{\text {front }}$ of $200 \mathrm{~cm} / \mathrm{s}$, a $L_{\text {eff }}$ of $24 \mu \mathrm{m}$ is obtained. Simulated $J_{s c}$ obtained from this simulation are displayed in Fig. 3(a). 
In order to investigate the dependence of resistive loss on $W_{B S F}$ variation, $R_{S}$ was estimated. Contact resistances were chosen to be $(60 \pm 10) \mathrm{m} \Omega \mathrm{cm}^{2}$ and $(335 \pm 70) \mathrm{m} \Omega \mathrm{cm}^{2}$ for $\mathrm{Si} / \mathrm{aSi}: \mathrm{H}(\mathrm{n}) / \mathrm{ITO} / \mathrm{Ag}$ and $\mathrm{Si} / \mathrm{aSi}: \mathrm{H}(\mathrm{i} / \mathrm{p}) / \mathrm{ITO} / \mathrm{Ag}$ contacts, respectively [22]. The calculation method of $R_{s}$ based on geometry of IBC-SHJ cell is reported in [35]. The fill factor $(F F)$ is calculated with the equation [36]:

$$
F F=F F_{0}\left(1-\frac{R_{s} \times J_{s c}}{V_{o c}}\right)
$$

$F F_{0}$ is determined for $W_{B S F}=120 \mu \mathrm{m}$ with $F F$ of $74.7 \%$ as obtained in Ref. [22].

Simulated $J_{s c}$ and calculated $F F$ as a function of $W_{B S F}$ are shown in Fig. 3(a). One can see that $J_{s c}$ decreases sharply with increase in $W_{B S F}$ due to the decrease in amount of photo-generated carriers in the emitter region. However, an increase in $W_{B S F}$ leads to a decrease in contact resistance at BSF region, thus $F F$ increases. $F F$ increases gradually with an increase in $W_{B S F}$ as soon as $W_{B S F}$ exceeds $60 \mu \mathrm{m}$. Assuming that $V_{o c}$ is $640 \mathrm{mV}$ and $650 \mathrm{mV}$, the cell efficiency $(\eta)$ can reach highest value at a $W_{B S F}$ of $60 \mu \mathrm{m}$ (Fig. 3(b)). For $W_{B S F}>60 \mu \mathrm{m}, \eta$ is dominated by the decrease in $J_{s c}$. Therefore, a sharp decrease in $\eta$ can be seen as $W_{B S F}$ increases.

\subsection{Experimental results}

We fabricated more than 150 cells with various $W_{B S F}$ on sixteen $5 \times 5 \mathrm{~cm}^{2}$ samples. Only cells without shunting issues (pseudo fill factor $(p F F) \geq 70 \%$ from Suns-Voc measurement) were taken into account. Fig. 4 shows $J_{s c}, V_{o c}, F F$ and $\eta$ of these cells as a function of $W_{B S F}$. A clear trend of decrease in $J_{s c}$ when $W_{B S F}$ increases can be seen. $V_{o c}$ and $\eta$ are comparable for all samples. The mean $F F$ increases with increasing $W_{B S F}$ as in the simulation results. This is also in agreement with the $R_{S}$ extracted from the comparison of dark and illumination $J$ - $V$ curves shown in Fig. 5. FFs of more than $70 \%$ were achieved for $W_{B S F}$ of $240 \mu \mathrm{m}, 120 \mu \mathrm{m}$ and $60 \mu \mathrm{m}$. One can see in Fig. 5 that there is a large deviation for the average $R_{S}$ from theoretical values. It might be related to the variation of doping concentration or contact resistance due to inhomogeneity in surface texture and/or absorber quality. However, for some of the best cells with low $R_{s}$, an agreement in theoretically and experimentally determined $R_{s}$ can be observed.

Fig. 6 displays the $J$ - $V$ curves of the best cell performance for each $W_{B S F}$. The parameters are listed in Table 2. The cells were measured with an additional anti-reflective foil (ARF) on the glass side to enhance light trapping [37]. By using an ARF, $J_{s c}$ can gain up to $10 \%$, raising efficiency around $10 \%$. The highest efficiency is $14.2 \%$ for the cell with $W_{B S F}$ of $120 \mu \mathrm{m}$, becoming a new record for (IBC-SHJ cell) for LPC-Si on glass. This efficiency is higher than that of IBC-SHJ cell of nano-textured $10 \mu \mathrm{m}$-mono c-Si absorber (13.7\%) [38]. It is also equivalent to the efficiency of state of the art a-Si:H/ $\mu \mathrm{c}-\mathrm{Si}: \mathrm{H} / \mu \mathrm{c}-\mathrm{Si}: \mathrm{H}$ triple junction cell $(14 \%)$ [39]. The highest obtained $V_{o c}$ value was $661 \mathrm{mV}$. This value is comparable with a $V_{o c}$ of state of the art multi-crystalline Si cell $[9,40]$. The results indicate the high potential of LPC-Si on glass in thin-film solar cell application.

\subsection{Discussion}




\subsubsection{Cell performance with various BSF widths}

In this part, we took parameters of the best performance cell without ARF for each $W_{B S F}$ to make a comparison, as displayed in Table 2. An efficiency of $13.6 \%$ is obtained for a $W_{B S F}$ of $60 \mu \mathrm{m}$. For cells with $W_{B S F}$ of $240 \mu \mathrm{m}$, the highest $V_{o c}$ value of $661 \mathrm{mV}$ was achieved. This high $V_{o c}$ implies that this cell might lie on a very good grains with a low grain boundary density. However, the $F F$ of $70.2 \%$ limits the efficiency to $12.8 \%$. Theoretically, the highest $F F$ would be obtained for the largest $W_{B S F}$ since it has the lowest contact resistance. A possible reason for lower experimental $F F$ is that this cell is located on grains with strongly tilted pyramids or flat surfaces, so that surface area is smaller, thus, the contact resistance is higher. Such a scenario could also explain why this cell has a high $V_{o c}$ since back-surface passivation is better on flat surfaces than textured surfaces. In order to estimate the potential of the cells with $W_{B S F}$ of 60 $\mu \mathrm{m}$ and $240 \mu \mathrm{m}$, we recalculated the $F F$ of these cells based on the $F F$ of the cell with $W_{B S F}$ of $120 \mu \mathrm{m}$ because for this $W_{B S F}$ the experimental $F F$ fits very good with the theoretical one determined by simulation. For these cells, a $F F$ of $75.9 \%$ and $72.8 \%$ can be achieved, as shown in Table 2. However, $J_{s c}$ of the cell with $W_{B S F}$ of $60 \mu \mathrm{m}$ is lower than the simulated one, therefore its $\eta$ is lower than that of the cell with $W_{B S F}$ of $120 \mu \mathrm{m}$. A simulated $J_{s c}$ of $27.8 \mathrm{~mA} / \mathrm{cm}^{2}$ can be found with $W_{B S F}$ of $60 \mu \mathrm{m}$, leading to $\eta$ of $13.1 \%$ and $\eta$ of $14.4 \%$ can be estimated for the cell measured with ARF. The reason for lower experimental $J_{s c}$ might be due to the difference in absorber quality of these cells, such as more grain boundaries or dislocations. $N_{D}$ of these samples is in the range of $8 \times 10^{16} \mathrm{~cm}^{-3}$, which lies between low and high doping cell reported in Ref. [22]. However, the $V_{o c}$ is higher than the $V_{o c}$ in the $13.2 \%$ efficiency cell with high doped absorber. This fact implies that samples in this study might have better absorber quality and/or surface passivation quality than the previous ones. In the next section, we will clarify the key factors contributing to the improvement of the cell performance by comparing the $14.2 \%$ efficiency cell in this study to the $13.2 \%$ efficiency cells reported in [22].

\subsubsection{The route to the efficiency of $14.2 \%$ in comparison to $13.2 \%$ cell}

In this part, we will analyze the surface recombination, the bulk quality as well as the series resistance of the $14.2 \%$ efficiency cell in comparison to the previous $13.2 \%$ efficiency cells in order to clarify which factors contributed significantly to the improvement in efficiency. All experimental parameters of these cells are listed in Table 3.

\subsubsection{Front surface recombination and bulk quality analysis.}

Fig. 7 shows the absorption spectra of all layers in the $14.2 \%$ efficiency cell. The blue dotted curve displayed absorption calculated from measured reflection $(R)$ and transmission $(T)$ spectra $(1-R-T)$. Notice that the $14.2 \%$ efficiency cell was obtained for a sample with $\mathrm{ON}(\mathrm{ON})$ IL while the $13.2 \%$ efficiency cells were obtained for a sample with ONO IL. Therefore, the reflectance is different between these cells. The higher absorption in long wavelength region can make the $13.2 \%$ efficiency cells gain a calculated $J_{s c}$ of $0.6 \mathrm{~mA} / \mathrm{cm}^{2}$ higher than $J_{s c}$ of the 14.2\% efficiency cell, as shown in Figs. 2 and 7. Therefore, $13.2 \%$ efficiency cells has more potential in $J_{s c}$ than the $14.2 \%$ efficiency cell. As shown in Fig. 7, a potential $J_{s c}$ of $32.7 \mathrm{~mA} / \mathrm{cm}^{2}$ can be achieved for the $14.2 \%$ efficiency cell. Assuming a $V_{o c}$ of $661 \mathrm{mV}$ and $F F$ of $74.9 \%$ as demonstrated in this study, a high efficiency of $16 \%$ seems feasible. 
We used extracted absorption spectra from GenPro4 to calculate the charge carrier generation profiles in LPC-Si. Experimental data of 14.2\% efficiency cell was modeled using TCAD Sentaurus $^{\mathrm{TM}}$ to evaluate surface passivation and bulk quality. $S R V_{\text {front }}$ and $\tau$ were varied to obtain experimental $V_{o c}$ of $650 \mathrm{mV}$ and $J_{s c}$ of $26.53 \mathrm{~mA} / \mathrm{cm}^{2}$. For simple approach, we firstly assumed that the bulk quality does not change when ONO or ON(ON) IL is used. $\tau$ of $1 \mu \mathrm{s}$, which corresponds to bulk quality of LPC-Si using ONO IL, as mentioned in section 2.1, was used in this simulation. $S R V_{\text {front }}$ was varied from 0 to $200 \mathrm{~cm} / \mathrm{s}$. The simulation results are shown in Fig. 8(a). One can see that $J_{s c}$ increases strongly and $V_{o c}$ increases slowly with decreasing $S R V_{\text {front }}$. Interestingly, even if $S R V_{\text {front }}$ reduces to $0 \mathrm{~cm} / \mathrm{s}, V_{o c}$ and $J_{s c}$ cannot reach the experimental values. That strongly indicates that the bulk quality of LPC-Si using ON(ON) IL must be improved.

Next, we assume that $S R V_{\text {front }}$ does not change but the bulk quality does. A constant $S R V_{\text {front }}$ of $200 \mathrm{~cm} / \mathrm{s}$, which corresponds to surface passivation quality of ONO IL was implemented into simulation. $\tau$ was varied from $1 \mu$ s to $1.55 \mu \mathrm{s}$. In this case, $\tau$ should be larger than $1 \mu \mathrm{s}$ to get $J_{s c} \geq 26.0 \mathrm{~mA} / \mathrm{cm}^{2}$. Simulated $J_{s c}$ and $V_{o c}$ are displayed in Fig. 8(b). One can see that when $\tau$ reaches $1.55 \mu \mathrm{s}, J_{s c}$ is larger than $26.53 \mathrm{~mA} / \mathrm{cm}^{2}$, but $V_{o c}$ is less than $650 \mathrm{mV}$. Therefore, $S R V_{\text {front }}$ might be less than $200 \mathrm{~cm} / \mathrm{s}$. $S R V_{\text {front }}$ of $100 \mathrm{~cm} / \mathrm{s}$ was thus chosen for the simulation. Fig. 8(b) also shows $J_{s c}$ and $V_{o c}$ as function of $\tau$ at $S R V_{\text {front }}$ of $100 \mathrm{~cm} / \mathrm{s}$. Simulated $J_{s c}$ of $26.44 \mathrm{~mA} / \mathrm{cm}^{2}$ and $V_{o c}$ of $640 \mathrm{mV}$ match quite well to experimental data when $\tau$ equals $1.16 \mu \mathrm{s}$. However, the remaining difference of $10 \mathrm{mV}$ of $V_{o c}$ might be due to back-surface passivation since we used the same defect layer for $13.2 \%$ efficiency cells. Improvement in bulk quality of LPC-Si might have a positive effect on deposition of a-Si:H layers, thus, traps in defect layers should decrease. By reducing defect concentration in defect layer between LPCSi and a-Si:H interface, $V_{o c}$ of $650 \mathrm{mV}$ and $J_{s c}$ of $26.56 \mathrm{~mA} / \mathrm{cm}^{2}$ can be achieved for $S R V_{\text {front }}$ of $100 \mathrm{~cm} / \mathrm{s}$ and $\tau$ of $1.16 \mu \mathrm{s}$. These values fit well to the experimental values. Using this defect layer with $S R V_{\text {front }}$ of $200 \mathrm{~cm} / \mathrm{s}$ and $\tau$ of $1.35 \mu \mathrm{s}$, we also obtained $V_{o c}$ of $651 \mathrm{mV}$ and $J_{s c}$ of $26.47 \mathrm{~mA} / \mathrm{cm}^{2}$, which also match quite well with the experimental $V_{o c}$ and $J_{s c}$. However, bulk quality of absorber was improved with using ON(ON) IL, low $S R V_{\text {front }}$ of $100 \mathrm{~cm} / \mathrm{s}$ might be more reasonable since in LPC-Si technique, $\mathrm{Si}$ absorber is crystallized directly on the passivation layer.

In conclusion, a $S R V_{\text {front }}$ of $100 \mathrm{~cm} / \mathrm{s}$ and $\tau$ of $1.16 \mu \mathrm{s}$, which corresponding to a $L_{e f f}$ of 26 $\mu \mathrm{m}$ were estimated for LPC-Si absorber with ON(ON) IL. This IL benefits not only from field effect passivation of $\mathrm{SiN}_{\mathrm{x}}$ layer but also from the homogeneous passivation quality layer created by $\mathrm{N}_{2} \mathrm{O}$ plasma process. Therefore, $S R V_{\text {front }}$ of sample using $\mathrm{ON}(\mathrm{ON})$ ILs is better than that of sample using ONO ILs. According to analysis, a homogeneous $\mathrm{N}$-rich $\mathrm{SiO}_{\mathrm{x}} \mathrm{N}_{\mathrm{y}}$ layer was formed on ON stack by plasma oxidation process and a smooth IL/ LPC-Si interface can be observed by TEM images [24]. This homogeneous layer might support a uniform shield for LPC-Si from dislocation and/ or stacking fault generation at the interface during the crystallization process, thus, suppressing surface recombination and enhancing bulk quality.

\subsubsection{Series resistance analysis}

One important factor contributing the $14.2 \%$ cell is the high $F F$ of $74.9 \%$, which was achieved thanks to low series resistance $\left(R_{s}\right)$. Using comparison of dark and illuminated $J-V$ curve method to calculate $R_{s}$, a value of $1.13 \Omega \mathrm{cm}^{2}$ can be obtained for the cell. This value is close to the calculated $R_{s}$ using contact resistances of $60 \mathrm{~m} \Omega \mathrm{cm}^{2}$ and $335 \mathrm{~m} \Omega \mathrm{cm}^{2}$ for 
$\mathrm{Si} / \mathrm{aSi}: \mathrm{H}(\mathrm{n}) / \mathrm{ITO} / \mathrm{Ag}$ and $\mathrm{Si} / \mathrm{aSi}: \mathrm{H}(\mathrm{i} / \mathrm{p}) / \mathrm{ITO} / \mathrm{Ag}$ contact, respectively. It is also lower than $R_{s}$ of the $13.2 \%$ efficiency cell with high doped absorber even though its bulk resistance is slightly higher. Lower $R_{S}$ might be due to lower contact resistance of $14.2 \%$ efficiency cell. Higher bulk quality might result from fewer grain boundaries and/or crystal defects on the Si surface, thus, resistance loss from contact on grain boundaries can be suppressed. Moreover, it also offers a less defect Si surface for initial texturing process, which might result in better pyramid formation, supporting a larger surface area, thus decreasing the contact resistance.

\section{Outlook}

From the presented device loss analysis it can be stated that the bulk quality of LPC-Si is a key factor to improve cell performance. A potential $J_{s c}$ of $32.7 \mathrm{~mA} / \mathrm{cm}^{2}$ is feasible for $13 \mu \mathrm{m}$ thick cells without using any ARF, resulting in a cell with $\eta$ of $16 \%$ by assuming the highest $V_{o c}$ and $F F$ in this study $(661 \mathrm{mV} ; 74.9 \%)$ are achieved. An estimated $J_{s c}$ of $27.8 \mathrm{~mA} / \mathrm{cm}^{2}$ was obtained for the current quality of LPC-Si, in which $S R V_{\text {front }}$ of $100 \mathrm{~cm} / \mathrm{s}$ and $\tau$ of $1.16 \mu \mathrm{s}$ are representative values. They correspond to a $L_{\text {eff }}$ of $26 \mu \mathrm{m}$, which is still lower than half of $W_{B S F}$. Cell efficiency is mainly limited by recombination at grain boundaries and dislocations. In order to get $L_{\text {eff }} \geq 30 \mu \mathrm{m}, \tau$ should be increased further to values exceeding $1.6 \mu \mathrm{s}$. Then an estimated $J_{s c}$ of $29.0 \mathrm{~mA} / \mathrm{cm}^{2}$ can be achieved. A $S R V_{\text {front }}<10 \mathrm{~cm} / \mathrm{s}$ also can improve cell efficiency, however, it is a challenge to achieve this low $S R V$ for LPC-Si surface passivation technique, since the passivation layer need to be stable during the crystallization process. Methods to enhance bulk quality, such as passivating LPC-Si by H-rich $\mathrm{SiN}_{\mathrm{x}}$ firing or phosphorus gettering may be promising approaches. By increasing the LPC-Si thickness to $24 \mu \mathrm{m}$, which is close to $L_{\text {eff, }}$, potential $J_{s c}$ becomes $33.9 \mathrm{~mA} / \mathrm{cm}^{2}$. In order to further increase $J_{s c}$, it would be effective to reduce optical losses, e.g. decreasing ITO thickness, using nano imprinting at front Si surface [41-45], or optimization of back surface texturing. Optimization of $N_{d}$ is also a crucial step to increase cell efficiency. According to simulation, a moderate doping with $N_{d}$ of $4 \times 10^{16} \mathrm{~cm}^{-3}$ is the optimum value for both $120 \mu \mathrm{m}$ and $60 \mu \mathrm{m}$, as shown in Fig. 9. It is in good agreement with 1-D device simulations indicating that ideal dopant concentration of absorber thicknesses of $10-20 \mu \mathrm{m}$ is $2-6 \times 10^{16} \mathrm{~cm}^{-3}$ [13]. In order to increase $F F$, reducing contact resistance, especially at BSF contact should be considered. A nano-crystalline (nc)-Si:H film would be a nice option since it has higher conductivity than a-Si:H films. More importantly, improvement in back surface passivation of LPC-Si is still hidden factor and need further investigation for LPC-Si.

\section{Summary}

In conclusion, an efficiency as high as $14.2 \%$ was achieved for an IBC-SHJ cell of LPC$\mathrm{Si}$ on glass, thanks to the improvement in surface passivation and bulk quality by using $\mathrm{ON}(\mathrm{ON})$ ILs and development in cell fabrication processes. A mean $V_{o c}$ of $620 \mathrm{mV}$ and highest $V_{o c}$ of $661 \mathrm{mV}$ show the potential of LPC-Si in thin film solar cell technology. The absorption profile of the back-textured LPC-Si layer stack was simulated with GenPro4. The modeling of the IBCSHJ solar cell was carried out by TCAD-Sentaurus ${ }^{\mathrm{TM}}$. The $2 \mathrm{D}$ simulation results showed best agreement with experimental data for $S R V_{\text {front }}=100 \mathrm{~cm} / \mathrm{s}$ and $\tau=1.16 \mu \mathrm{s}$, which correspond to a $L_{\text {eff }}$ of $26 \mu \mathrm{m}$. According to simulated data, $N_{d}$ of $4 \times 10^{16} \mathrm{~cm}^{-3}$ and $W_{B S F}$ of $60 \mu \mathrm{m}$ are optimum values to maximise the cell efficiency. A potential efficiency of $16 \%$ was also estimated for the cells. However, at the present state the cell efficiency is limited by the bulk quality, a carrier lifetime of $1.16 \mu \mathrm{s}$ is not enough to achieve cells with efficiencies above $20 \%$. In order to get an efficiency comparable to mc-Si cells (21.5\%), besides techniques to enhance the absorber 
quality, it is necessary to introduce effective light trapping or light coupling technique to increase $J_{s c}$ to values exceeding $32 \mathrm{~mA} / \mathrm{cm}^{2}$. 


\section{Acknowledgment}

The authors would like to thank DSM Advanced Surfaces for providing the textured lighttrapping anti-reflection foil (ARF) and GP Solar for providing the Alkatex IPA-free texturing agent; R. Santbergen (TU-Delft) and D. Eisenhauer for optical simulation advices and support with GenPro4; J-C. Stang and G. Chistiakova for support with TCAD-Sentaurus ${ }^{\mathrm{TM}}$ simulations; J-C. Stang, L. Korte and T. Frijnts for interesting discussion; PECVD (AKT) team (PVcomB) for great help of a-Si:H film deposition; K. Jacob, M. Wittig, M. Hartig and K. M-Stillrich in solar cell preparation. 


\section{References}

[1] Int. Technol. Roadmap Photovoltaics. (2016). Int. Technol. Roadmap Photovoltaic. Results, 2016, Rev. 1 [Online]. Available: www.itrpv.net

[2] International Renewable Energy Agency, Renewable Energy Cost Analysis-Solar Photovoltaics (2012)

[3] K. R. Catchpole, M.J. McCann, K.J. Weber, A.W. Blakers, A review of thin-film crystalline silicon for solar cell applications. Part 2: Foreign substrates, Sol. Energy Mater. Sol. Cells 682 (2001) 173-215.

[4] T. Matsuyama, N. Terada, T. Baba, T. Sawada, S. Tsuge, K. Wakisaka, S. Tsuda, Highquality polycrystalline silicon thin film prepared by a solid phase crystallization method, J. of Non-Cryst. Solids 198-2 (1996) 940-944.

[5]I. Gordon, L. Carnel, D. Van Gestel, G. Beaucarne, J. Poortmans, 8 \% efficient thin-film polycrystalline-silicon solar cells based on aluminum-induced crystallization and thermal CVD, Progress in Photovoltaics: Research and Applications 15 (2007)

[6] L. Carnel, I. Gordon, D. Van Gestel, G. Beaucame, J. Poortmans, Efficient soar cells based on fine-grained polysilicon, Thin Solid films 516 (2008) 6839-6843.

[7] C. Becker, D. Amkreutz, T.Sontheimer, V. Preidel, D. Lockau, J. Haschke, L. Jogshies, C. Klimm, J. J. Merkel, P. Plocica, S. Steffens, B. Rech, Polycrystalline silicon thin-film solar cells: Status and perspectives, Sol. Energy Mater. Sol. Cells 119 (2013) 112-123.

[8] J. Dore, D. Ong, S. Varlamov, R. Egan, M.A. Green, "Progress in laser-crystallized thinfilm polycrystalline silicon solar cells: Intermediate layers, light trapping and metallization", IEEE Journal of Photovoltaics 4, 2014, pp. 33-39

[9] S. Kühnapfel, N.H. Nickel, S. Gall, M. Klaus, C. Genzel, B. Rech, D. Amkreutz, "Preferential $\{100\}$ grain orientation in 10 micrometer-thick laser crystallized multicrystalline silicon on glass", Thin Solid Films 576 (2015) 68-74.

[10] J. Haschke, D. Amkreutz, L. Korte, F. Ruske, B. Rech, Towards wafer quality crystalline silicon thin-film solar cells on glass, Sol. Energy Mater. Sol. Cells 128 (2014) 190-197.

[11] J. Haschke, D. Amkreutz, B. Rech, "Liquid phase crystallized silicon on glass: Technology, material quality and back contacted heterojunction cells", Jpn. J. Appl. Phys. 55 (2016) 04EA04 1-10.

[12] O. Schultz, S. W. Glunz, G. P. Willeke, Multicrystalline silicon solar cells exceeding 20\% efficiency, Prog. Photovolt. Res. Appl. 12(7) (2004) 553-558.

[13] D. Amkreutz, J. Haschke, S. Kühnapfel, P .Sonntag, B. Rech, Silicon thin-film solar cells on glass with open-circuit volatges above $620 \mathrm{mV}$ formed by Liquid-phase crystallization, IEEE J. Photovoltaics. 4-6 (2014) 1496-1501.

[14] O. Gabriel, T. Frijnts, N. Preissler, D. Amkreutz, S. Calnan, S. Ring, B. Stannowski, B. Rech, R. Schlatmann, Crystalline silicon on glass-interface passivation and absorber material quality, Prog. Photovoltaics Res. Appl. 24-2 (2016) 1499 -1512.

[15] N. Preissler, D. Amkreutz, P. Sonntag, M. Trahms, R. Schlatmann, B. Rech, Interface engineering for liquid-phase crystallized-silicon solar cells on glass, Sol. RRL 1 3-4 (2017) $17000151-5$.

[16] J. Dore, S. Varlamov, M.A. Green, Intermediate layer development for laser-crystallized thin-film silicon solar cells on glass, IEEE J. Photovoltaics 5 (2015) 9-16.

[17] J. Haschke, D. Amkreutz, T. Frijnts, S. Kuhnapfel, T. Hanel, B. Rech, Influence of barrier and doping type on the open-circuit voltage of liquid phase-crysllized silicon thin-film solar cells on glass, IEEE J. Photovoltaics 5-4, 1001 (2015) 1001-1005.

[18] D. Amkreutz, W.D. Barker, S. Kuhnapfel, P. Sonntag, O. Gabriel, S. Gall, U. Bloeck, J. Schmidt, J. Haschke, B. Rech, Liquid-phase crystallized silicon solar cells on glass: Increasing 
the open-circuit voltage by optimized interlayers for $\mathrm{n}$ - and p-type absorbers, IEEE J. Photovoltaics 5, 1757 (2015).

[19] J. Schmidt, B. Veith, R. Brendel, Effective surface passivation of crystalline silicon using ultrathin $\mathrm{Al}_{2} \mathrm{O}_{3}$ films and $\mathrm{Al}_{2} \mathrm{O}_{3} / \mathrm{SiN}_{\mathrm{x}}$ stacks, Phys. Status Solidi: Rapid Res. Lett. 3-9 (2009) 287-289.

[20] T. Frijnts, S. Kühnapfel, S. Ring, O. Gabriel, S. Calnan, J. Haschke, B. Stannowski, B. Rech, R. Schlatmann, Analysis of photo-current potentials and losses in thin film crystalline silicon solar cells, Sol. Energy Mater. Sol. Cells 143 (2015) 457-466.

[21] P. Sonntag, J. Haschke, S. Kühnapfel, O. Gabriel, D. Amkreutz, B. Rech, Properties of liquid phase crystallized interdigitated back-contact solar cells on glass. Energy Procedia 77 (2015) 487-492.

[22] P. Sonntag, N. Preissler, M. Bokalič, M. Filipič, M. Trahms, J. Haschke, R. Schlatmann Marko Topič, B. Rech, D. Amkreutz, Silicon solar cells on glass with power conversion efficiency above $13 \%$ at thickness below 15 micrometer, Sci. Rep. 7 (2017) 873 1-12.

[23] P. Sonntag, M. Bokalič, M. Filipič, T. Frijnts, D. Amkreutz, Marko Topič, B. Rech, Analysis of local minority carrier diffusion lengths in liquid phase crystallized silicon thin-film solar cells", IEEE Journal of Photovoltaics 7-1 (2017) 32-36.

[24] N. Preissler, C. T. Trinh, M. Trahms, P. Sonntag, D. Abou-Ras, H. Kirmse, R. Schlatmann, B. Rech, D. Amkreutz, Impact of dielectric layers on front-side passivation of liquid phase crystallized silicon solar cells on glass, in Proceedings of the $44^{\text {th }}$ IEEE PVSC, 2017 (submitted).

[25]D. Pysch, A. Mette, S.W. Glunz, A review and comparison of different methods to determine the series resistance of solar cells, Sol. Energy Mater. Sol. Cells 91 (2007) 16981706.

[26] SYNOPSYS. Sentaurus Structure Editor User Guide. F-2011.09, September 2011

[27] R. Santbergen, T. Meguro, T. Suezaki, G. Koizumi, K. Yamamoto, and M. Zeman, GenPro4 optical model for solar cell simulation and its application to multifunction solar cells, IEEE journal of photovoltaics 7-3 (2017) 919-926.

[28] C.V. Cushman, B.A. Sturgell, A.C. Martin, B.M. Lunt, N.J. Smith, and M.R. Linford, Eagle $\mathrm{XG}{ }^{\circledR}$ glass, optical constants from 230 to $1690 \mathrm{~nm}(0.73-5.39 \mathrm{eV})$ by spectroscopic ellipsometry, Surf. Sci. Spectra 23 (2016) 55-60.

[29] M.A. Green, Self-consistent optical parameters of intrinsic silicon at $300 \mathrm{~K}$ including temperature coefficients, Sol. Energy Mater. Sol. Cells 92 (2008) 1305-1310.

[30] D. Zhang, I.A. Digday, R. Santbergen, R.A.C.M.M. van Swaaij, P. Bronsveld, M. Zeman, J.A.M. van Roosmalen, A.W. Weeber, Design and fabrication of SiOx/ITO double-layer antireflective coating for heterojuction silicon solar cells, Sol. Energy Mater. Sol. Cells 117 (2013) 132.

[31] P. B. Johnson and R. W. Christy, Optical Constants of Noble Metals, Physical Review B, Volume 6, Number 12, 1972, pp. 4370-4379

[32] J. G. Fossum and D. S. Lee, A physical model for the dependence of carrier lifetime on doping density in nondegenerate silicon, Solid-State Electron. 25-8 (1982) 741-747.

[33] J. G. Fossum, Computer-aided numerical analysis of silicon solar cells, Solid-State Electronics 19 (1976) 269-277.

[34] M. Filipič, Z.C. Holman, F. Smole, S. De Wolf, C. Ballif, M. Topič, Analysis of lateral transport through the inversion layer in amorphous silicon/crystalline silicon heterojunction solar cells, J. Appl. Phys. 114 (2013) 74504.

[35] Y. Yang, G. Xu, K. Zhang, X. Zhang, H. Shen, P. A. Altermatt, P. J. Verlinden, Z. Feng, Analysis of series resistance of industrial crystalline silicon solar cells by numerical simulation and analytical modelling, in Proc. $28^{\text {th }}$ Eur. Photovoltaic Sol. Energy Conf. Exhib. (2013) 15591561. 
[36] M. A. Green. Solar cells: Operating principles, technology, and system applications, Prentice-Hall Inc., Englewood Cliffs, 1982, p. 288

[37] C. Ulbrich, A. Gerber, K. Hermans, A. Lambertz, U. Rau, Analysis of short circuit current gains by an anti-reflective textured cover on silicon thin film solar cells. Prog. Photovoltaics Res. Appl. 21 (8), (2013) 1672.

[38] S. Jeong, M.D. McGehee, Y. Cui, All-back-contact ultra-thin silicon nanocone solar cells with 13.7\% power conversion efficiency, Nat. Commun. 4 (2013) 2950 1-7.

[39] H, Sai, T. Matsui, K. Matsubara, Stabilized 14.0\% -efficient triple-junction thin-film silicon solar cell”, Appl. Phys. Lett. 109 (2016) 183506 1-5.

[40] Martin A. Green, Corrigendum to Solar cell efficiency tables (version 49), Prog. Photovolt: Res. Appl. 24 (2016) 905-913.

[41] G. Köppel, V. Preidel, S. Mangold, E. Rudigier-Voigt, M. Hývl, A. Fejfar, B. Rech, C. Becker, Nanoimprint-textured glass superstrates for light trapping in crystalline silicon thinfilm solar cells, Energy Procedia 84 (2015) 118-126.

[42] C. Becker, V. Preidel, D. Amkreutz, J. Haschke, B. Rech, Double-side textured liquid phase crystallized silicon thin-film solar cells on imprinted glass, Sol. Energy Mater. Sol. Cells 135 (2015) 2-7

[43] G. Köppel, B. Rech, C. Becker, Sinusoidal nanotextures for light management in silicon thin-film solar cells, Nanoscale 8 (2016) 8722-8728.

[44] D. Eisenhauer, G. Köppel, K. Jäger, D. Chen, O. Shargaieva, P. Sonntag, D. Amkreutz, B. Rech, C. Becker, Smooth anti-reflective three-dimensional textures for liquid phase crystallized silicon thin-film solar cells on glass. Sci. Rep. 7 (2017) 2658 1-10.

[45] K. Jäger, C. Barth, M. Hammerschmidt, S. Herrmann, S. Burger, F. Schmidt, C. Becker, Simulations of sinusoidal nanotextures for coupling light into c-Si thin-film solar cells, Opt. Express 24 (2016) A569-A580 


\section{Figure captions}

Fig. 1. Top-view from back side of a sample after (a) emitter structuring (b) back surface field structuring (c) electrodes structuring. (d) Cross sectional structure of an IBC-SHJ cell.

Fig. 2. (a) AFM image of a textured LPC-Si on glass. (b) Absorption spectra of all layers in an IBC-SHJ cell with ONO IL simulated by GenPro4. Blue dot curve indicates experimental 1-R$\mathrm{T}$ of this sample.

Fig. 3. (a) $J_{s c}$ and $F F$ as functions of $W_{B S F} . J_{s c}$ are simulated values from $2 \mathrm{D}$-simulation with $\tau$ of $1 \mu \mathrm{s}, S R V_{\text {front }}$ of $200 \mathrm{~cm} / \mathrm{s}$ and $N_{D}$ of $8 \times 10^{16} \mathrm{~cm}^{-3}$ are input parameters for LPC-Si. FFs are obtained from Equation (3). (b) Efficiency $(\eta)$ of IBC cell with various $W_{B S F}$ at $V_{o c}$ of 640 and $650 \mathrm{mV}$.

Fig. 4. Experimental $J_{s c}, V_{o c}, F F$ and $\eta$ as a function of $W_{B S F}$.

Fig. 5. $R_{S}$ determined from comparison of dark and illuminated $J-V$ curves at various $W_{B S F}$. Star dots represent theoretical value calculated based on geometry of IBC-SHJ cell following Ref [35].

Fig. 6. The $J-V$ curves of the best cells with $W_{B S F}$ of 60,120 and $240 \mu \mathrm{m}$.

Fig. 7. Absorption spectra of all layers in an IBC-SHJ cell with ON(ON) IL simulated by GenPro4. Blue dot curve indicates experimental $1-R-T$ of this sample. Experimental $1-R-T$ of the sample with ONO IL is also shown in asterisk curve for comparison.

Fig. 8. (a) $J_{s c}$ and $V_{o c}$ as functions of $S R V_{\text {front }}$ at $\tau$ of $1 \mu \mathrm{s}$. (b) Dependence of $J_{s c}$ and $V_{o c}$ on $\tau$ at $S R V_{\text {front }}$ of 100 and $200 \mathrm{~cm} / \mathrm{s}$. Blue and black lines represents for the experimental $V_{o c}$ and $J_{s c}$, respectively. Opened and filled stars display simulated $J_{s c}$ and $V_{o c}$ with lower defect concentration at a-Si:H/LPC-Si interface.

Fig. 9. Simulated efficiency as a function of $N_{D}$ with $W_{B S F}$ of $60 \mu \mathrm{m}$. 
Table 1. Experimental and simulated data of cells with different $N_{D}$. Experimental data of low and high doped cells are taken from Ref. [22]. $J_{s c}$ and $V_{o c}$ for medium doped cell are simulated results with input parameters extracted from simulation for low and high doped cells.

\begin{tabular}{|c|c|c|c|c|c|c|c|c|}
\hline \multirow{2}{*}{$\begin{array}{c}\text { Cell } \\
\text { Doping } \\
\text { level }\end{array}$} & $N_{D}\left(\mathrm{~cm}^{-3}\right)$ & \multicolumn{2}{|c|}{$V_{o c}(\mathrm{mV})$} & \multicolumn{2}{c|}{$J_{s c}\left(\mathrm{~mA} / \mathrm{cm}^{2}\right)$} & $\begin{array}{c}S R V \\
(\mathrm{~cm} / \mathrm{s})\end{array}$ & $\begin{array}{c}\tau \\
(\mu \mathrm{s})\end{array}$ & $\begin{array}{c}L_{\text {eff }} \\
(\mu \mathrm{m})\end{array}$ \\
\cline { 3 - 9 } & Experimental & Simulated & Experimental & Simulated & & & & \\
\hline Low & $1.2 \times 10^{16}$ & 620 & 613 & 28.1 & 28.1 & 200 & 1.8 & 30 \\
\hline High & $1.2 \times 10^{17}$ & 635 & 636 & 25.2 & 25.2 & 200 & 0.8 & 20 \\
\hline Medium* & $8 \times 10^{16}$ & -- & 635 & -- & 27.4 & 200 & 1.0 & 24 \\
\hline
\end{tabular}

Table 2. Cell parameters at different $W_{B S F}$ with and without ARF. $F F$ and $\eta$ after $F F$ recalculation also listed for comparison.

\begin{tabular}{|c|c|c|c|c|c|c|c|}
\hline \multicolumn{2}{|c|}{$W_{B S F}$} & $\begin{array}{c}J_{s c} \\
\left(\mathrm{~mA} / \mathrm{cm}^{2}\right)\end{array}$ & $\begin{array}{c}V_{o c} \\
(\mathrm{mV})\end{array}$ & \multicolumn{2}{c|}{$F F(\%)$} & \multicolumn{2}{c|}{$\eta(\%)$} \\
\cline { 4 - 8 } & & & Experimental & Recalculate & Experimental & Recalculate \\
\hline $\begin{array}{c}240 \\
\mu \mathrm{m}\end{array}$ & $\begin{array}{c}\text { With } \\
\text { ARF }\end{array}$ & 26.9 & 661 & 72.20 & 75.98 & 12.84 & 13.51 \\
\cline { 2 - 8 } & $\begin{array}{c}\text { Without } \\
\text { ARF }\end{array}$ & 25.197 & 651 & 72.50 & 75.98 & 11.89 & 12.46 \\
\hline $\begin{array}{c}120 \\
\mu \mathrm{m}\end{array}$ & $\begin{array}{c}\text { With } \\
\text { ARF }\end{array}$ & 28.978 & 654 & 74.94 & 74.94 & 14.20 & 14.20 \\
\cline { 2 - 8 } & $\begin{array}{c}\text { Without } \\
\text { ARF }\end{array}$ & 26.53 & 650 & 74.84 & 74.84 & 12.91 & 12.91 \\
\hline $\begin{array}{c}60 \\
\mu \mathrm{m}\end{array}$ & $\begin{array}{c}\text { With } \\
\text { ARF }\end{array}$ & 29.683 & 646 & 70.94 & 72.73 & 13.61 & 13.95 \\
\cline { 2 - 8 } & $\begin{array}{c}\text { Without } \\
\text { ARF }\end{array}$ & 27.143 & 639 & 70.94 & 72.73 & 12.34 & 12.61 \\
\hline
\end{tabular}


Table 3. Cell parameter of the best cell in this study and $13.2 \%$ efficiency cells from Sonntag et al. [22]. The cells were measured with and without ARF.

\begin{tabular}{|c|c|c|c|c|c|c|c|c|}
\hline Cell & ILs & $\mathrm{N}_{\mathrm{D}}\left(\mathrm{cm}^{-3}\right)$ & \multicolumn{2}{|c|}{$W_{B S F}$} & $J_{s c}$ & $V_{o c}$ & $F F$ & $\eta(\%)$ \\
\hline \multirow{2}{*}{$\begin{array}{c}\text { Sonntag et. } \\
\text { al }\end{array}$} & \multirow{2}{*}{ ONO } & \multirow[t]{2}{*}{$1.2 \times 10^{16}$} & \multirow{2}{*}{$\begin{array}{l}120 \\
\mu \mathrm{m}\end{array}$} & With ARF & 31.3 & 626 & 67.2 & 13.2 \\
\hline & & & & $\begin{array}{c}\text { Without } \\
\text { ARF }\end{array}$ & 28.1 & 620 & 67.2 & 11.9 \\
\hline \multirow{2}{*}{$\begin{array}{c}\text { Sonntag et. } \\
\text { al }\end{array}$} & \multirow[t]{2}{*}{ ONO } & \multirow[t]{2}{*}{$12 \times 10^{16}$} & \multirow{2}{*}{$\begin{array}{l}120 \\
\mu \mathrm{m}\end{array}$} & With ARF & 27.5 & 642 & 74.7 & 13.2 \\
\hline & & & & $\begin{array}{c}\text { Without } \\
\text { ARF }\end{array}$ & 25.2 & 635 & 74.7 & 11.9 \\
\hline \multirow[t]{2}{*}{ This study } & \multirow[t]{2}{*}{$\mathrm{ON}(\mathrm{ON})$} & \multirow[t]{2}{*}{$8 \times 10^{16}$} & \multirow{2}{*}{$\begin{array}{l}120 \\
\mu \mathrm{m}\end{array}$} & With ARF & 28.98 & 654 & 75 & 14.21 \\
\hline & & & & $\begin{array}{c}\text { Without } \\
\text { ARF }\end{array}$ & 26.53 & 650 & 75 & 12.91 \\
\hline
\end{tabular}


Fig. 1

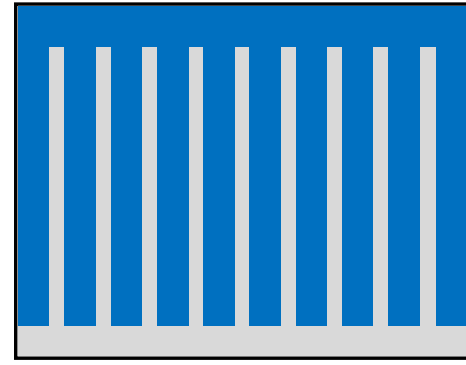

After emitter structuring

(a)

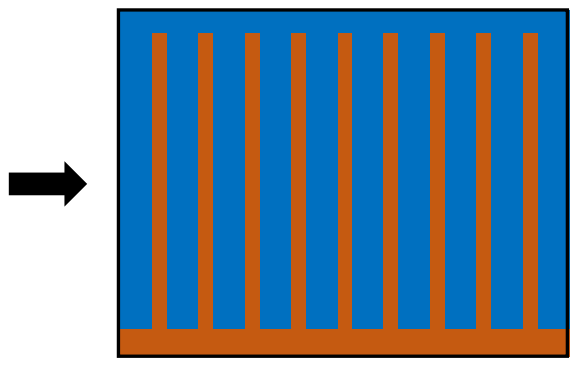

After BSF structuring

(b)

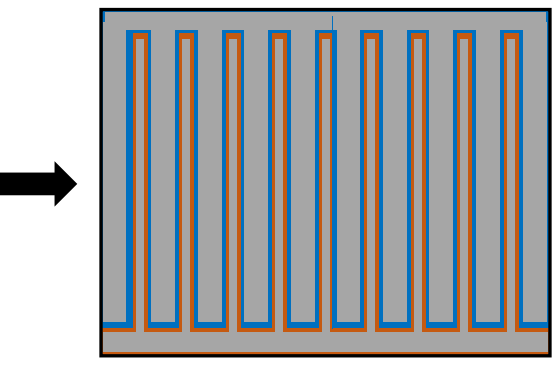

After electrodes structuring

(c)

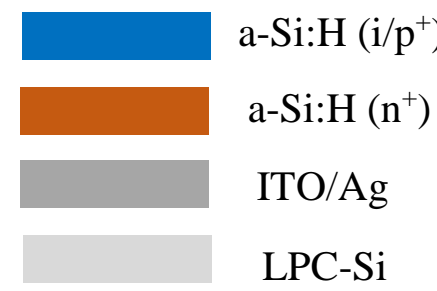

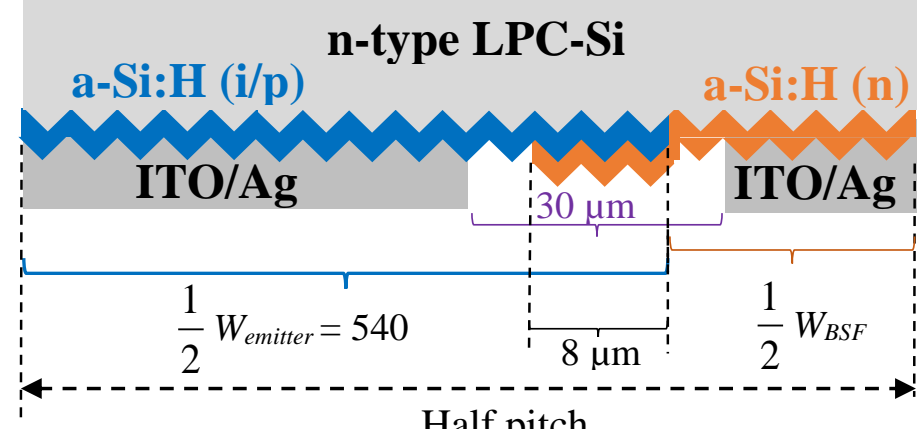

Half pitch

(d) 
Fig. 2

(a)
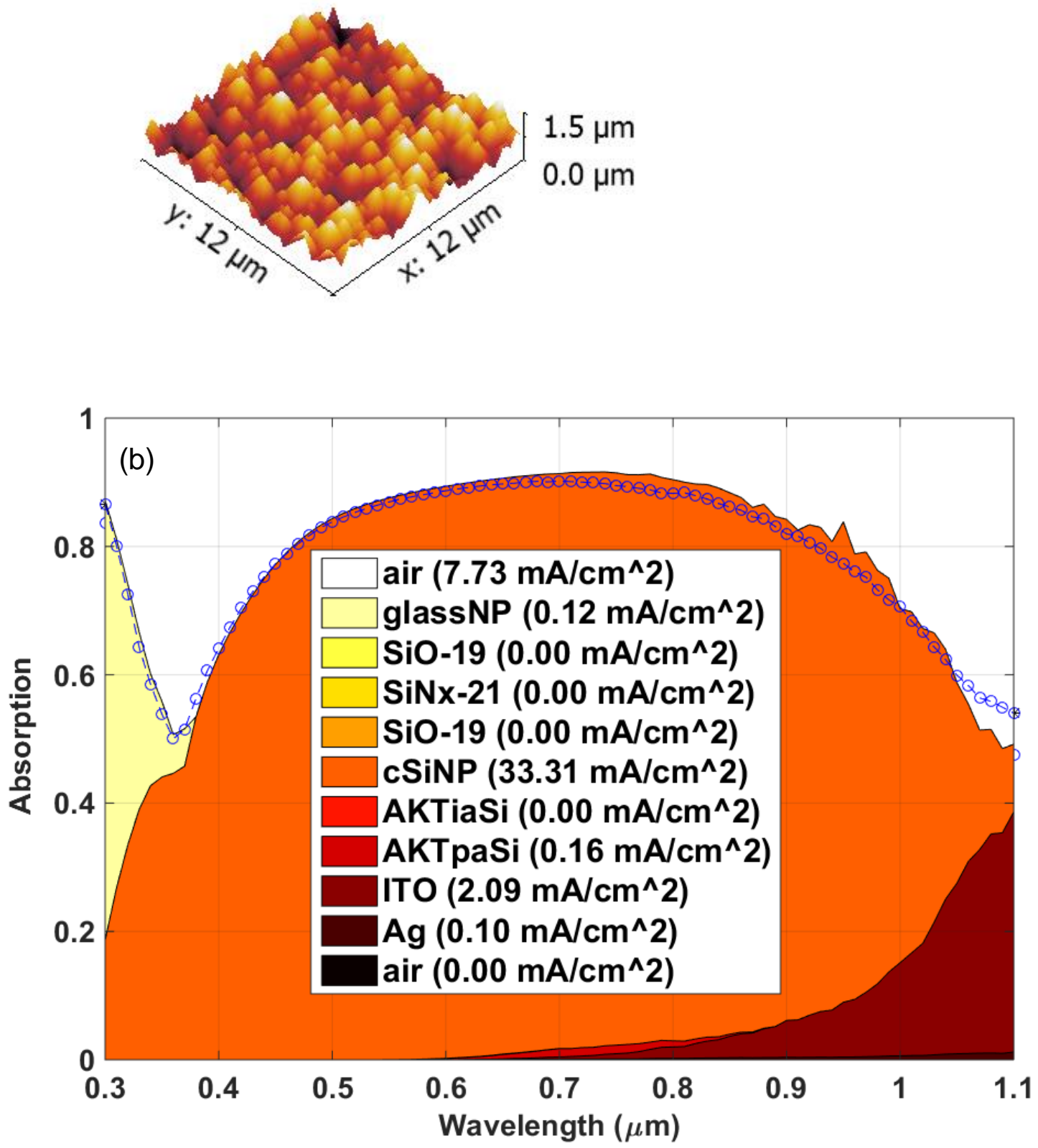
Fig. 3
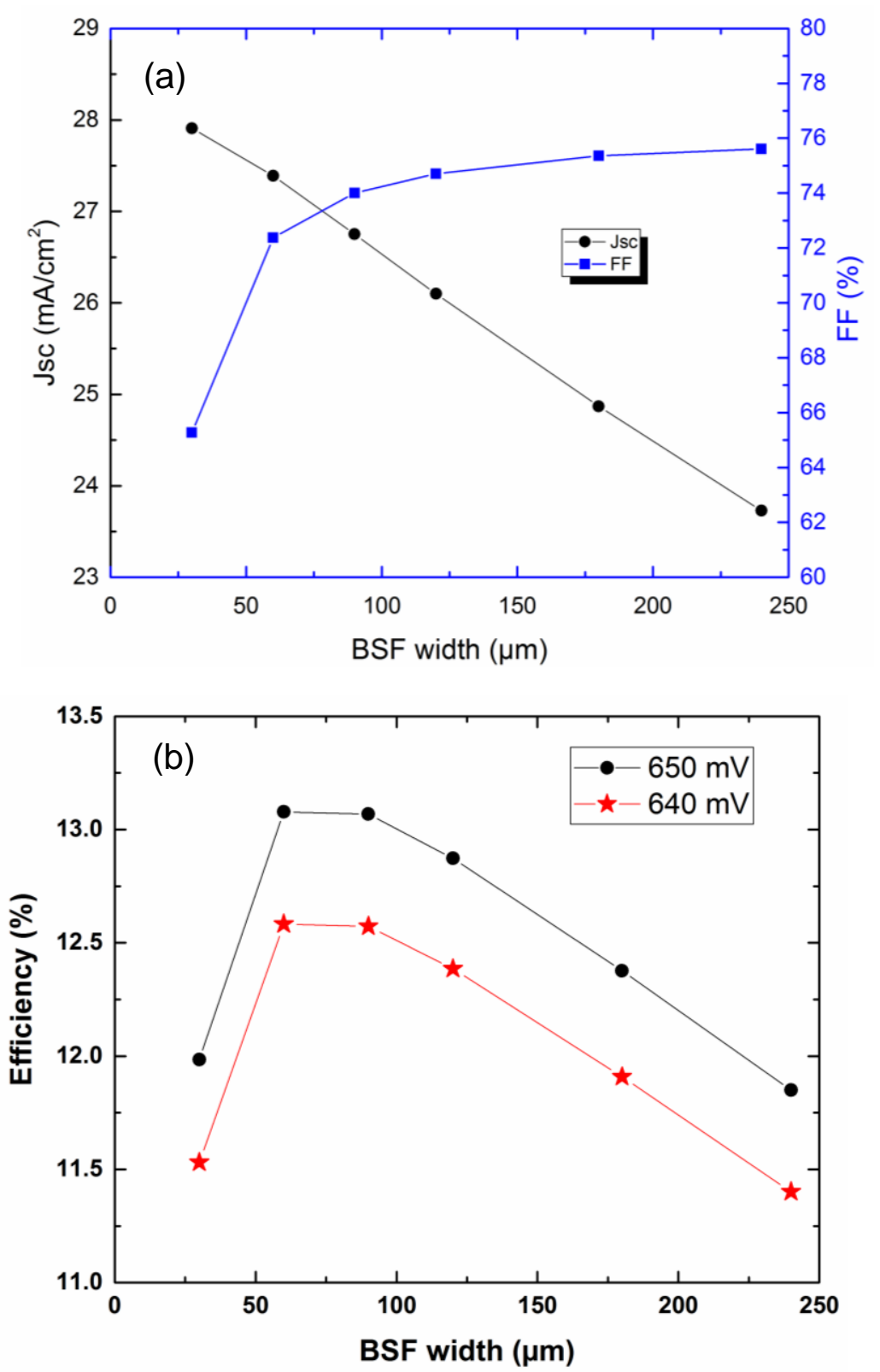
Fig. 4
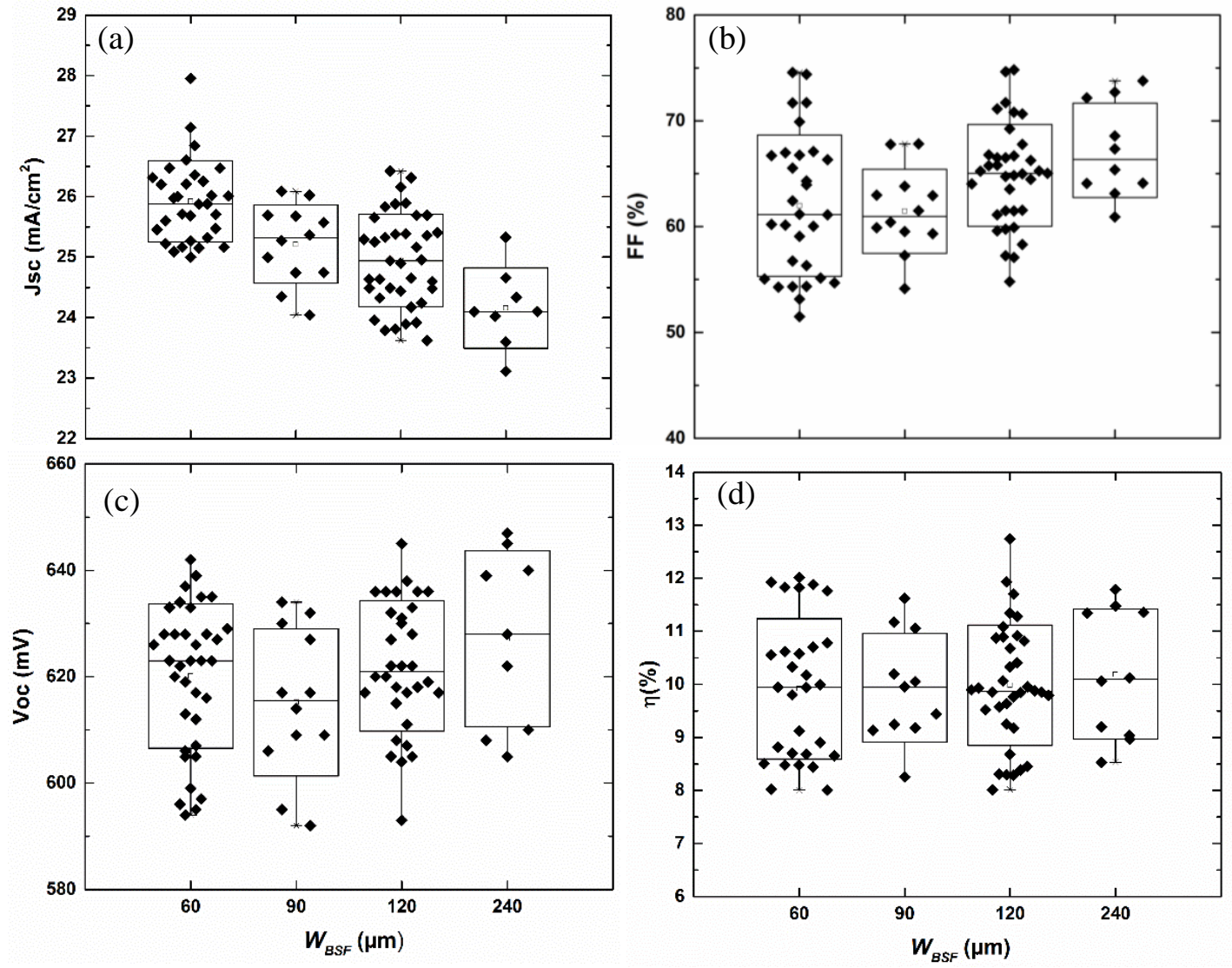
Fig. 5

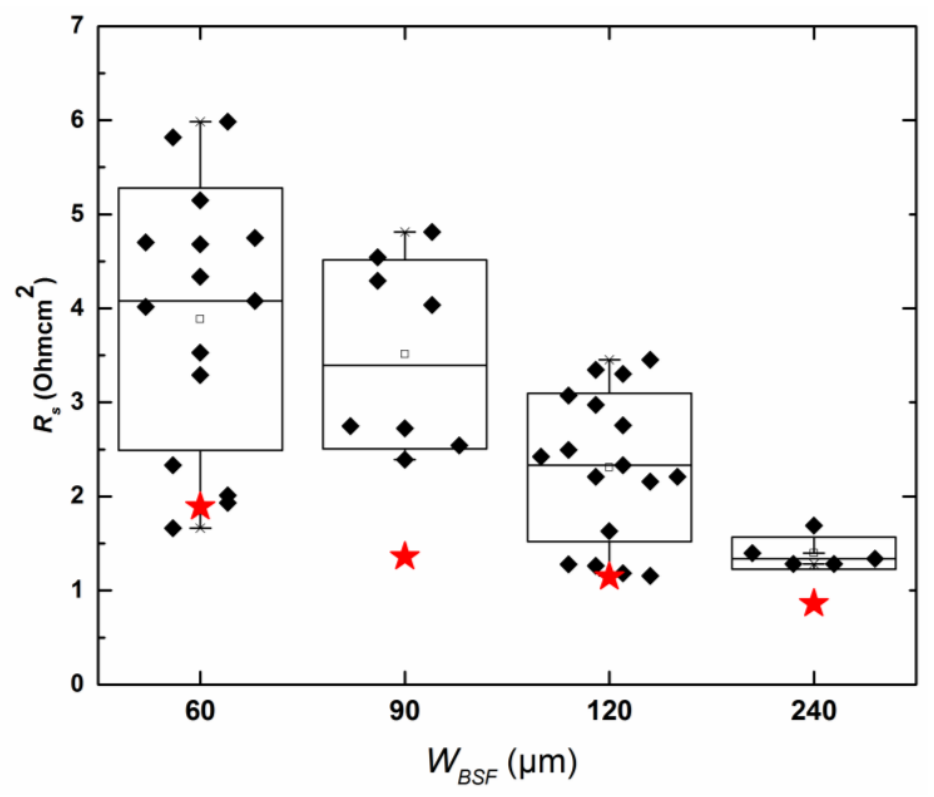


Fig. 6

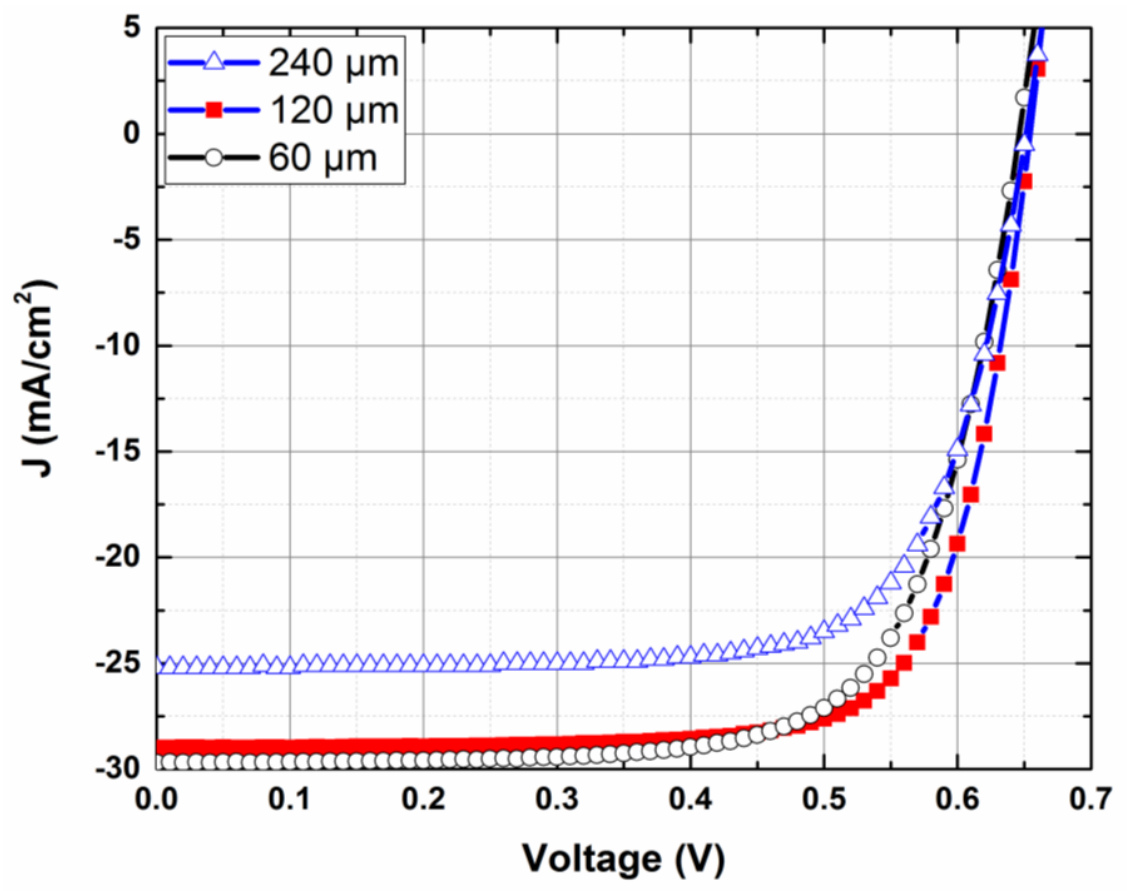


Fig. 7

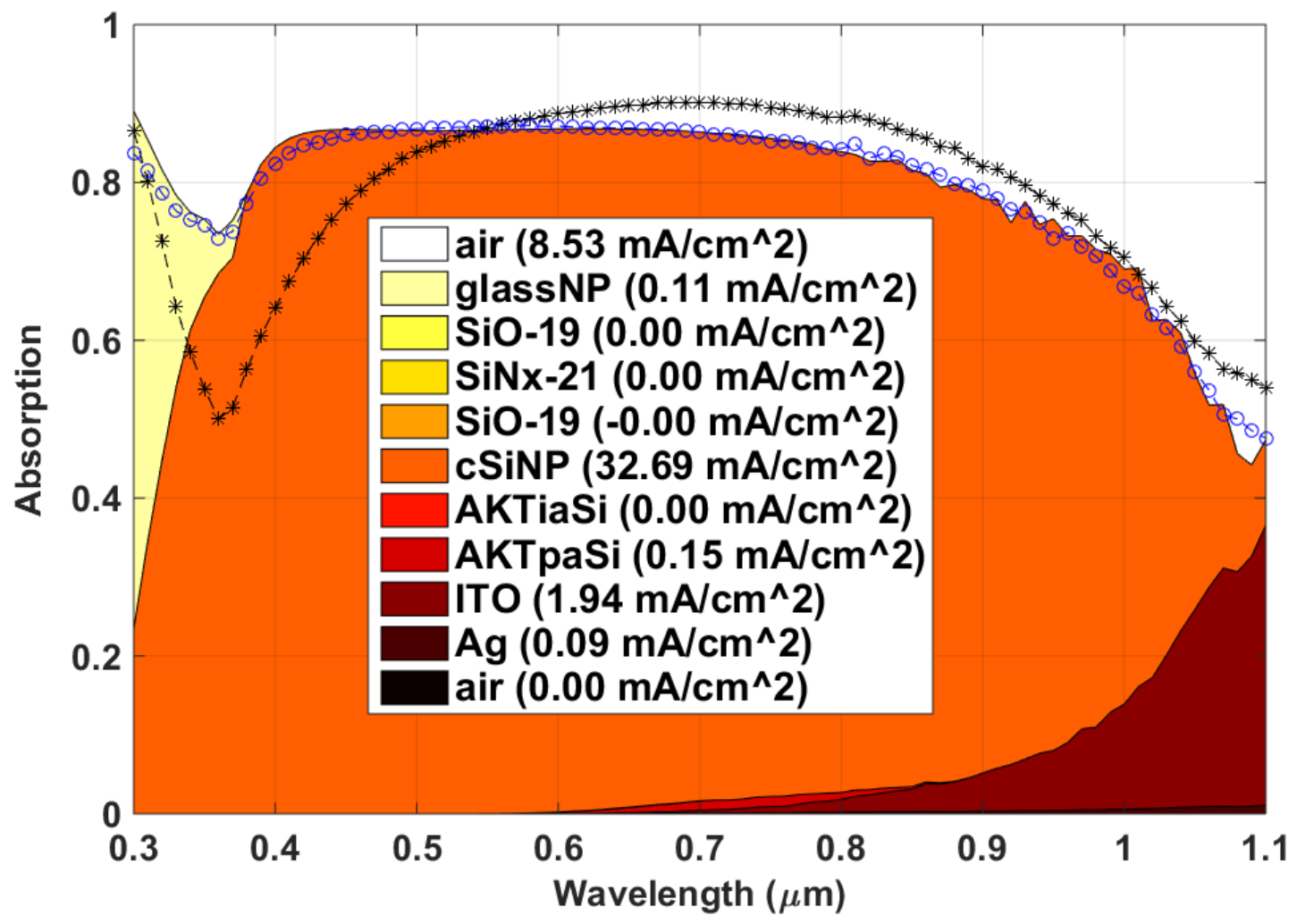


Fig. 8
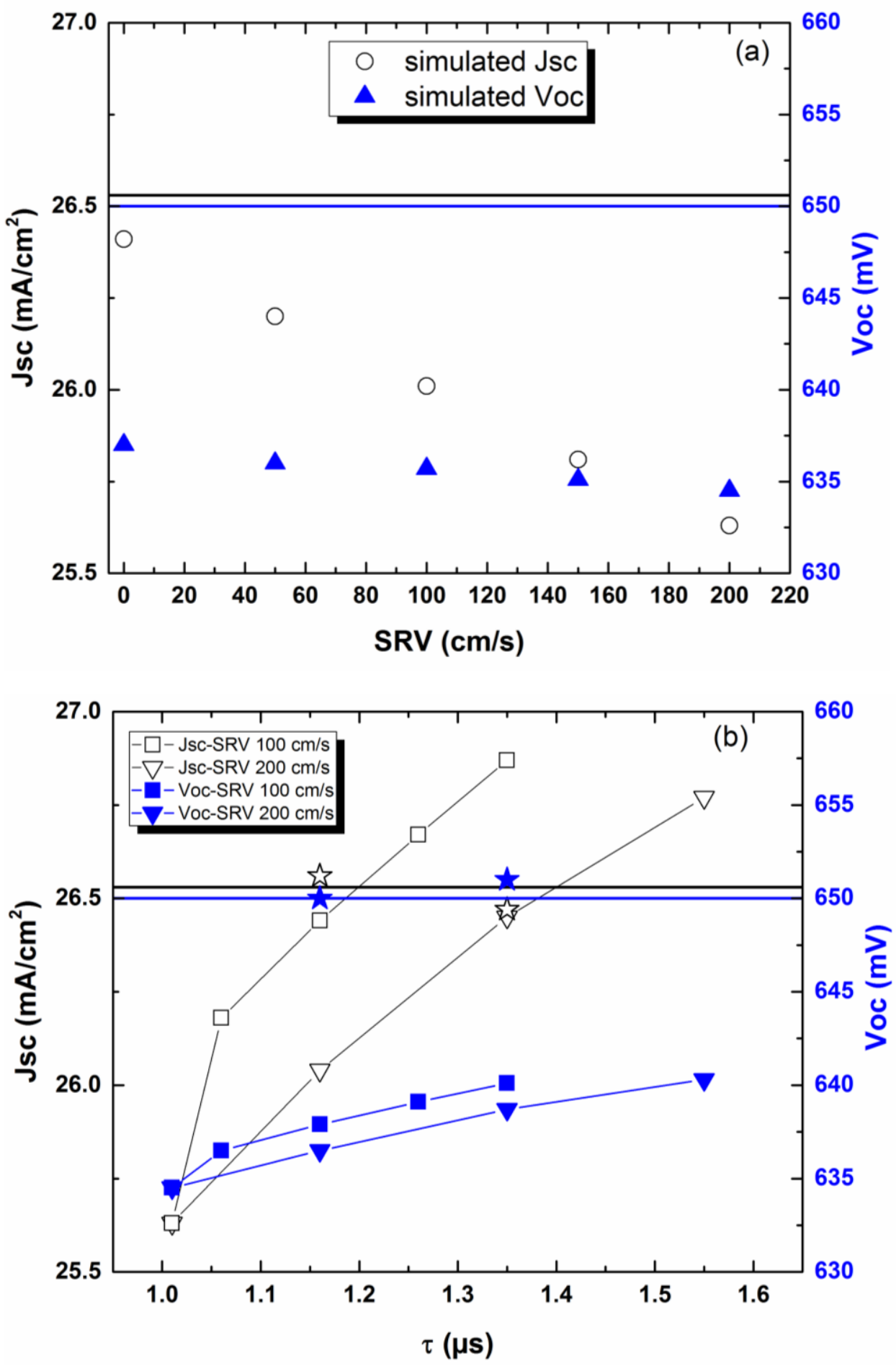
Fig. 9

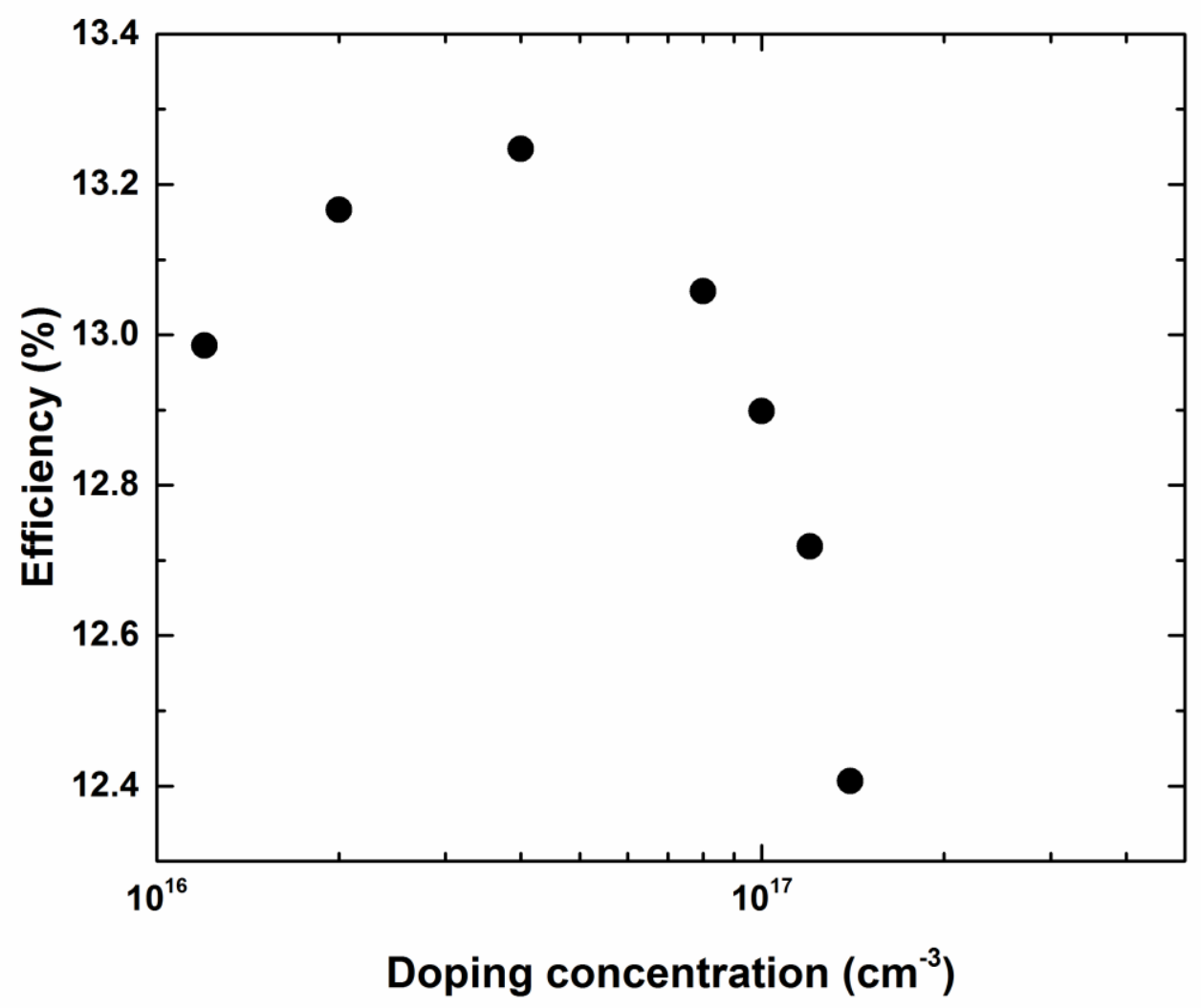


